\title{
The regulation of protein content and quality in national and international food standards
}

\author{
Janine L. Lewis* \\ Food Standards Australia New Zealand, Canberra, Australia \\ (Submitted 26 July 2011 - Final revision received 21 September 2011 - Accepted 16 November 2011)
}

\begin{abstract}
Food regulation aims to protect public health through a safe and nutritious food supply produced by a compliant food industry. Food standards of developed countries generally do not regulate protein content or protein quality because the risk of dietary protein inadequacy in their national populations is very low. Protein is nevertheless regulated for reasons of product quality or protein labelling or to minimise assessed health risks associated with consumption of certain animal- and vegetable-protein foods; analogue products that extend or simulate commonly available animal-protein foods; and special purpose foods such as infant formula and foods, supplementary and medical foods, and foods for weight loss. The extent and approach to protein regulation varies greatly among jurisdictions but where it occurs, it is applied through minimum and sometimes maximum limits on protein content or quality measures or both using an interrelated approach. Protein quality measures range from amino acid profiles and digestibility corrected scores to protein rating, a rat bioassay and reference proteins not further described. Regulatory methods for protein quality determination are referenced to the published scientific literature or developed nationally. Internationally, the Codex Alimentarius regulates the protein content and quality of some foods. The Codex approach varies according to the food but is similar to the approaches used in national and regional food regulation. This paper provides a comparison of the regulation of protein in foods using examples from the food regulations of Australia New Zealand, Canada, the European Union, the United States of America and the Codex Alimentarius.
\end{abstract}

Key words: Protein content: Protein quality: Food standards: Food regulation

\section{Introduction}

Food regulation is established by national and regional authorities and internationally to control and guide the food industry in producing and marketing safe food. A primary objective of food regulation is to protect the health of consumers. Other objectives may also be established, for example, Australia New Zealand (Australia and New Zealand adopted joint food standards in the year 2000) has two additional statutory objectives: the provision of adequate information to enable informed choice; and the prevention of misleading or deceptive conduct ${ }^{(1)}$.

At the international level, food regulatory measures are developed by the Codex Alimentarius Commission (Codex) and its committees established under the Joint Food Standards Programme of the Food and Agriculture Organization of the United Nations and the World Health Organization. Codex has the dual purpose of protecting consumer health and ensuring fair trade practices so as to promote global harmonisation of food regulation and to facilitate international trade in food $^{(2)}$. Codex texts in the form of food standards, guidelines, codes of practice and other recommendations are collected into the Codex Alimentarius ${ }^{(3)}$ which is used by Codex members as a benchmark in developing food regulation for their jurisdictions.

National and regional authorities and the Codex system apply a risk analysis approach to the development of food regulation that considers the risks to health as well as other factors including consumer impacts and the economic costs and benefits. Codex texts are usually derived from the regulatory experience of Codex members.

This paper presents an overview and comparison of the regulation of protein content and protein quality of foods in Australia New Zealand ${ }^{(4)}$, Canada ${ }^{(5)}$, Europe ${ }^{(6)}$, the United States of America ${ }^{(7)}$ and Codex Alimentarius ${ }^{(3)}$. Relevant provisions in the food regulations of these jurisdictions were identified by means of helpful advice from regulators in jurisdictions and from an online search using the terms 'protein' and 'amino'. Because some food regulation codes/texts can be searched only one standard at a time, some relevant texts might have been missed particularly for commodity foods. The term 'regulation' in this paper is applied generically although in some jurisdictions the term is applied to a particular food standard. 


\section{Overview of regulation of protein in food}

The majority of foods in the surveyed jurisdictions and Codex are not regulated for protein content or protein quality. Populations in these jurisdictions are at very low risk of protein inadequacy because of the abundance of available high quality protein from animal foods. However, protein content, protein quality and their methods of measurement are regulated for particular foods.

Protein is variously regulated to:

- manage the natural variation in protein composition of certain commodity foods for product quality reasons;

- manage health risks related to the role of the food in the national diet or diets of vulnerable population subgroups;

- provide consistent and appropriate label information about protein in food to consumers;

- ensure consistency and certainty of measurement for enforcement and compliance purposes.

There are five elements that can be used to regulate the protein content and quality of foods. These elements are:

1. criteria for protein content;

2. methods of analysis of protein content;

3. nitrogen conversion factors;

4. criteria for protein quality;

5. methods of determination of protein quality.

The elements are applied generally according to the following regulatory outcomes:

- protein content criteria for product quality reasons

- protein content and quality criteria for the management of assessed health risks associated with consumption of:

-certain animal- and vegetable-protein foods

-analogue foods that extend or simulate commonly available animal-protein foods

-special purpose foods comprising infant formula and foods, supplementary foods, foods for weight loss and medical foods;

- protein content criteria for protein label declaration and claims about protein content;

- designated chemical methods and/or nitrogen factors for analysis of protein content;

- designated biological or chemical protein quality measures and accompanying methods for the determination of protein quality.

Criteria for protein content and protein quality and their methods are prescribed either singly or in combination depending on the jurisdiction and the nature and purpose of the food. Protein content criteria are always set as minimum amounts although maximum amounts can also apply, mostly for special purpose foods. Some protein content and quality criteria are inter-related especially for special purpose foods. Methods of protein analysis are predominantly the official methods of the Association of Official Analytical Chemists $(\mathrm{AOAC})^{(8)}$ although official methods of international industry or standards organisations are also included in the Codex
Alimentarius $^{(3)}$. Nitrogen factors are prescribed with or without listed analytical methods even though many prescribed methods of protein analysis include reference to a specific nitrogen factor. Several protein quality measures are available for use. Methods of determination of protein quality, where prescribed, range from chemical to biological methods to a national protein rating scheme.

\section{Protein regulation in more detail}

Although there are some common features as described above, the specific details vary considerably among the jurisdictions and Codex both in relation to the foods selected and the use of the five elements. Even where all surveyed jurisdictions and Codex regulate protein in the same food, there are considerable differences in the approach taken. This variability is partly due to the rolling and subject-specific nature of food regulatory development and revision in the different regulatory systems of the jurisdictions and Codex that attend to matters at a particular point in time.

Details of the regulation of protein in the jurisdictions and Codex are set out in four tables (Tables 1-4). The first three of these provide a qualitative overview of the use of the five elements of protein regulation according to the type and purpose of the food. The fourth table focuses on the specific details of protein quality regulation listing each protein quality measure in order.

Table 1 relates to commodity and analogue foods. Regulation of protein in these foods ranges from the use of a single element to all five elements, or several combinations of an intermediate number of elements. Nearly all foods are prescribed minimum protein content criteria expressed as gram amounts per quantity of food. Macaroni and noodle products are not prescribed minimum protein contents although a maximum amount applies when gum gluten is added. Codex soy protein products are prescribed both a minimum and maximum protein content criterion. About half the number of foods has a prescribed method of analysis and half of these methods are accompanied by a specified nitrogen factor. Protein quality is prescribed for some commodity and all analogue foods and is set as a proportion of the protein quality of casein or untreated egg whites or as a protein rating. Codex Alimentarius ${ }^{(3)}$ has adopted minimum protein content criteria for several commodity foods including cooked, cured meat products; milk products; cereal flours and meals. Only a few of these foods are listed in Table 1 owing to their large number. The Codex Alimentarius ${ }^{(3)}$ consolidated all methods of analysis and determination for all analytes and foods into one standard ${ }^{(9)}$. One to three methods of protein analysis are listed for each regulated commodity but only one method of analysis and one method of protein quality determination are listed for the group of special purpose foods.

Protein regulation for special purpose foods varies between two and five elements as shown in Table 2. More extensive regulation of protein in special purpose foods reflects the increased health risk and vulnerability of the subpopulations for which these foods are intended. Nearly all foods have 
prescribed quality measures and methods of determination but less than half of these have listed methods of analysis. More nitrogen factors are listed without a method of analysis than with one and where specified, nitrogen factors are either generic or specific to the food matrix.

Protein content is established by minimum criteria expressed as gram amounts per $100 \mathrm{~kJ} / \mathrm{kcal}$, per $100 \mathrm{~g}$ or per daily amount of food, or as a percentage of a food's energy value. Maximum criteria are also set for infant and followon/up formulas and some processed infant cereals. Codex has recently updated its methods of analysis for infant formula, including for protein content and nitrogen factors ${ }^{(10)}$, and these methods are awaiting official publication. Minimum protein quality measures are established for most special purpose foods either as a minimum amino acid composition or as a minimum proportion of the quality of casein or other reference protein. Many special purpose foods are permitted the addition of specified or unspecified L-amino acids but only in amounts and for the purpose of improving protein quality. Protein quality methods range from chemical methods to a biological method to a national protein rating scheme ${ }^{(11)}$.

Regulation of protein labelling shown in Table 3 involves the use of one to four elements other than methods of analysis, but no more than three elements by any one jurisdiction or Codex. Criteria for 'source', 'good or excellent/high source' or 'more/increased' protein content claims are established in all jurisdictions and Codex, but only in Canada is protein quality routinely used to regulate protein content claims. The United States is the only jurisdiction that uses protein quality criteria to modify the usual declaration of protein content for foods of poorer protein quality.

\section{Protein quality}

Protein quality is characterised by one of five measures:

1. amino acid composition or reference amino acid profile;

2. protein digestibility-corrected amino acid score;

3. protein efficiency ratio;

4. protein rating;

5. reference protein without amino acid profile or method of determination.

Each jurisdiction and Codex draws on more than one measure of protein quality to regulate protein in a range of foods. Similarly, no protein quality measure is adopted by the jurisdictions and Codex for the same food. The widest use of a common protein quality measure is for infant formula regulated by Australia New Zealand, Europe and Codex.

Protein quality criteria can be established independently from, or related to, protein content. Certain regulations in

Table 1. Regulation of protein in commodity and analogue foods ${ }^{(4-7)}$

\begin{tabular}{|c|c|c|c|c|c|c|c|}
\hline Food group & Food & Jurisdiction & $\begin{array}{l}\text { Protein } \\
\text { content }^{*}\end{array}$ & $\begin{array}{l}\text { Nitrogen } \\
\text { factor }\end{array}$ & $\begin{array}{l}\text { Method(s) } \\
\text { of analysis }\end{array}$ & $\begin{array}{l}\text { Protein } \\
\text { quality } †\end{array}$ & $\begin{array}{l}\text { Quality } \\
\text { measure }\end{array}$ \\
\hline \multirow[t]{2}{*}{$\begin{array}{l}\text { Analogue animal } \\
\text { foods }\end{array}$} & $\begin{array}{l}\text { Meat product extender; poultry product } \\
\text { extender; simulated meat products; } \\
\text { simulated poultry products }\end{array}$ & Canada & 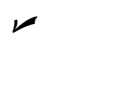 & & & レ‡ & Protein rating \\
\hline & $\begin{array}{l}\text { Simulated whole egg (with egg } \\
\text { albumin) }\end{array}$ & Canada & レ & & & レ & Protein rating \\
\hline \multirow{5}{*}{$\begin{array}{l}\text { Cereals and } \\
\text { cereal products }\end{array}$} & Flour & United States & & $5 \cdot 7$ & 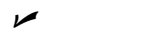 & & \\
\hline & Macaroni products & United States & $\nu \S$ & & & & \\
\hline & $\begin{array}{l}\text { Macaroni-enriched products with } \\
\text { fortified protein }\end{array}$ & United States & $\swarrow$ & $6 \cdot 25$ & 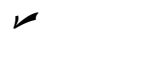 & 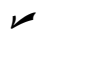 & PER \\
\hline & Noodle products & United States & $\nu \S$ & & & & \\
\hline & Wheat flour & Codex & $\nu$ & $5 \cdot 7$ & 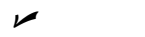 & & \\
\hline \multirow[t]{6}{*}{ Dairy foods } & $\begin{array}{l}\text { Acidified milks, yoghurt (addition of } \\
\text { certain dairy ingredients) }\end{array}$ & United States & 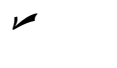 & & & 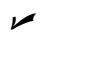 & PER \\
\hline & Cow's milk & $\begin{array}{l}\text { Australia } \\
\text { New Zealand }\end{array}$ & 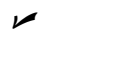 & & & & \\
\hline & Drinking milk & European Union & $\swarrow$ & & & & \\
\hline & Fermented milks, yoghurt & Codex & 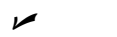 & & 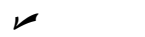 & & \\
\hline & Milk powder & Codex & $\nu$ & & 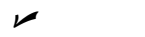 & & \\
\hline & Whey and variations of whey & United States & $\nu$ & & レ & & \\
\hline Eggs & Dried egg whites & United States & & & & 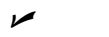 & PER \\
\hline \multirow[t]{2}{*}{ Food supplement } & Fish protein isolate & United States & $\swarrow$ & $6 \cdot 25$ & 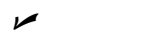 & & \\
\hline & Whole fish protein concentrate & United States & $\swarrow$ & $6 \cdot 25$ & 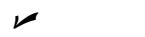 & 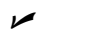 & PER \\
\hline \multirow[t]{2}{*}{ Legume products } & $\begin{array}{l}\text { Peanut spreads ( }<90 \% \text { peanuts) } \\
\text { considered as nutritionally } \\
\text { equivalent to peanut butter }\end{array}$ & United States & 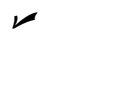 & & 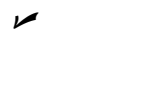 & 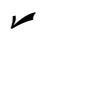 & PER \\
\hline & Soy flour; concentrate; isolate & Codex & $\boldsymbol{\nu \|}$ & $6 \cdot 25$ & 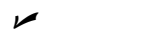 & & \\
\hline Dinners & Frozen 'heat and serve' dinner & United States & 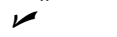 & & & & \\
\hline
\end{tabular}

PER, protein efficiency ratio

$\checkmark$ Indicates the use of a particular regulatory element in protein regulation.

${ }^{*}$ Minimum protein content criteria (except for foods marked by §)

$\dagger$ Minimum protein quality criteria

$\ddagger$-amino acid addition permitted only to improve protein quality. Permissions specifically given for each food or, in the case of United States, generically given subject to certain conditions including that the food contains at least $6.5 \mathrm{~g}$ primarily-intact protein in a reasonable daily adult intake $(21 \mathrm{CFR} 172.320)^{(7)}$

$\S$ Maximum protein content criteria only; applies only where gum gluten is added

॥ Minimum and maximum protein content criteria 


\section{N British Journal of Nutrition}

Table 2. Regulation of protein in special purpose foods ${ }^{(4-7,11)}$

\begin{tabular}{|c|c|c|c|c|c|c|c|}
\hline Food group & Food & Jurisdiction & Protein content ${ }^{*}$ & Nitrogen factor & $\begin{array}{l}\text { Method(s) } \\
\text { of analysis }\end{array}$ & $\begin{array}{l}\text { Protein } \\
\text { quality }\end{array}$ & Quality measure \\
\hline \multirow[t]{3}{*}{ Follow-on formula } & Follow-on formula & Australia New Zealand & r‡ & 6.38 milk 6.25 other & & $\boldsymbol{\nu \S}$ & Amino acid profile \\
\hline & $\begin{array}{l}\text { Follow-on formula manufactured from: } \\
\text { cows' milk proteins; protein } \\
\text { hydrolysates; or soya protein } \\
\text { isolates alone or in combination } \\
\text { with cows' milk proteins }\end{array}$ & European Union & V‡ & $6 \cdot 25$ & & $\nu \S$ & Amino acid profile \\
\hline & Follow-up formula & Codex & $\boldsymbol{\nu \neq , \|}$ & & $\boldsymbol{\nu}$ & $\nu \S$ & PER \\
\hline Foods for medical purposes & Formulated liquid diet & Canada & レ\| & & & $\boldsymbol{\nu \S}$ & Protein rating \\
\hline \multirow[t]{2}{*}{$\begin{array}{l}\text { Foods for older infants and } \\
\text { young children }\end{array}$} & Processed cereal-based foods & Codex & レヘ & & $\boldsymbol{r}$ & レ§ & $\begin{array}{l}\text { Chemical index (added protein) or } \\
\text { PER (final food) }\end{array}$ \\
\hline & $\begin{array}{l}\text { Processed cereal-based foods and } \\
\text { baby foods }\end{array}$ & European Union & レq & & & $\boldsymbol{\nu \S}$ & $\begin{array}{l}\text { Chemical index (added protein) or } \\
\text { PER (final food) }\end{array}$ \\
\hline \multirow[t]{5}{*}{ Infant formula } & Infant formula & Australia New Zealand & $\nu \ddagger$ & 6.38 milk 6.25 other & & $\nu \S$ & Amino acid profile \\
\hline & Infant formula & Codex & レ‡ & $\begin{array}{l}6.25 \text { or if justified, } 6.38 \\
\text { milk and } 5.71 \text { soy }\end{array}$ & $\boldsymbol{\nu}$ & & Amino acid profile \\
\hline & $\begin{array}{l}\text { Infant formula manufactured from: } \\
\text { cows' milk proteins; protein } \\
\text { hydrolysates; or soya protein } \\
\text { isolates alone or in combination } \\
\text { with cows' milk proteins }\end{array}$ & European Union & レ‡ & $6 \cdot 25$ & & & Amino acid profile \\
\hline & $\begin{array}{l}\text { Infant formula (new or major change } \\
\text { in formulation) }\end{array}$ & United States & レ‡,\| & & $\boldsymbol{r}$ & $\boldsymbol{\nu \S}$ & PER \\
\hline & Human milk substitute & Canada & $\boldsymbol{\nu \neq , \|}$ & & & $\nu \S$ & Relative to casein \\
\hline \multirow[t]{4}{*}{ Supplementary foods } & Formulated supplementary foods & Australia New Zealand & V & & & & \\
\hline & $\begin{array}{l}\text { Formulated supplementary foods for } \\
\text { older infants and young children }\end{array}$ & Codex & $\boldsymbol{v}$ & & $\boldsymbol{r}$ & $\boldsymbol{\nu \S}$ & PDCAAS or PER \\
\hline & $\begin{array}{l}\text { Formulated supplementary foods for } \\
\text { young children }\end{array}$ & Australia New Zealand & $\boldsymbol{V}$ & & & & \\
\hline & Nutritional supplement & Canada & $\boldsymbol{\nu \|}$ & & & $\boldsymbol{\nu}$ & Relative to casein \\
\hline \multirow[t]{6}{*}{ Weight loss foods } & $\begin{array}{l}\text { Foods intended for use in energy- } \\
\text { restricted diets for weight reduction }\end{array}$ & European Union & レ‡,\| & & & $\nu \S$ & PDCAAS \\
\hline & $\begin{array}{l}\text { Foods represented for use in very low } \\
\text { energy diets }\end{array}$ & Canada & $\boldsymbol{V \|}$ & & & $\boldsymbol{\nu}$ & Relative to casein \\
\hline & $\begin{array}{l}\text { Formula foods for use in very low } \\
\text { energy diets for weight reduction }\end{array}$ & Codex & $\boldsymbol{V}$ & & $\boldsymbol{\nu}$ & v§ & PDCAAS \\
\hline & $\begin{array}{l}\text { Formula foods for use in weight } \\
\text { control diets }\end{array}$ & Codex & レ‡,\| & & $\boldsymbol{r}$ & & Relative to casein \\
\hline & Meal replacement & Australia New Zealand & $\boldsymbol{\nu}$ & & & & \\
\hline & Meal replacement & Canada & $\boldsymbol{\nu \|}$ & & & $\boldsymbol{\nu}$ & Relative to casein \\
\hline
\end{tabular}

PER, protein efficiency ratio

PDCAAS, protein digestibility corrected amino acid score

Indicates the use of a particular regulatory element in protein regulation.

* Minimum protein content criteria, except where qualified by (ף)

$\dagger$ Minimum protein quality criteria

\ Maximum protein content criteria
L-amino acid addition permitted only to improve protein quality. Permissions specifically given for each food or, in the case of United States, generically given subject to certain conditions including that the food contains at least 6.5g primarily-intact protein in a reasonable daily adult intake 21CFR172.320(7)

Minimum protein content related to high quality reference protein. If protein quality lower than reference protein, then protein content of food must be increased proportionately

I Minimum protein content criteria apply only to the added high protein ingredient; maximum content criteria apply to total protein content of foods with added high protein ingredient 
Table 3. Regulation of protein in nutrition labelling ${ }^{(4-7)}$

\begin{tabular}{|c|c|c|c|c|c|c|}
\hline Labelling element & Jurisdiction & $\begin{array}{l}\text { Protein } \\
\text { content }^{*}\end{array}$ & $\begin{array}{l}\text { Nitrogen } \\
\text { factor }\end{array}$ & $\begin{array}{l}\text { Method } \\
\text { of analysis }\end{array}$ & $\begin{array}{l}\text { Protein } \\
\text { quality }\end{array}$ & Quality measure \\
\hline \multirow[t]{5}{*}{ Protein content claim } & $\begin{array}{l}\text { Australia New Zealand } \\
\quad \text { (draft) }^{(25)}\end{array}$ & $\boldsymbol{V}$ & & & & \\
\hline & Canada & レ‡ & & & レ‡ & Protein rating \\
\hline & Codex & $\boldsymbol{V}$ & $6 \cdot 25$ & & & \\
\hline & European Union & $\nu$ & $6 \cdot 25$ & & & \\
\hline & United States & $\boldsymbol{V}$ & & & & \\
\hline $\begin{array}{l}\text { Protein declaration in } \\
\text { nutrition labelling }\end{array}$ & United States & & & & レ & $\begin{array}{l}\text { PDCAAS for } \geq 1 \text { year age; } \\
\text { PER for infants }\end{array}$ \\
\hline
\end{tabular}

PDCAAS, protein digestibility corrected amino acid score

PER, protein efficiency ratio

$\nu$ Indicates the use of a particular regulatory element in protein regulation.

${ }^{*}$ Minimum protein content criteria

† Minimum protein quality criteria

$\ddagger$ Minimum protein content related to high quality reference protein. If protein quality lower than reference protein, then protein content of food must be increased proportionately

Canada, the United States and Codex inter-relate protein content and quality such that protein content criteria are set according to a high standard of protein quality of a reference protein. However, a food is permitted to contain poorer quality protein providing it has a proportionately higher quantity of protein than that set for the high quality protein. This compensatory provision may be accompanied by a minimum protein quality established as a proportion of the reference protein quality.

The infant formula regulation in the United States provides a worked example of the relation between protein content and quality based on a minimum protein content of $1.8 \mathrm{~g}$ per 100 kilocalories with a protein quality equivalent to casein, as prescribed in 21 CFR107.100 ${ }^{(7)}$ :

Protein shall be present in an amount not less than 1.8 grams per 100 kilocalories of infant formula when its protein quality is equivalent to or better than that of casein. If the protein quality is less than that of casein, the minimum amount of protein shall be increased proportionately to compensate for its lower quality. For example, an infant formula containing protein with a biological quality of 75 percent of casein shall contain at least $2 \cdot 4$ grams of protein $(1 \cdot 8 / 0 \cdot 75)$. No protein with a biological quality less than 70 percent of casein shall be used.

Another example is quoted from the Canadian Food and Drug Regulations ${ }^{(5)}$ (B.25.054) for human milk substitute (infant formula):

Per 100 available kilocalories

Not less than 1.8 grams of protein of nutritional quality equivalent to that of casein, or such an amount and quality of protein, including those proteins to which amino acids are added, that, when the quality of the protein is expressed as a fraction of the quality of casein,

(A) the fraction will not be less than $85 / 100$, and

(B) the product obtained by multiplying the fraction by the gram weight of the protein will not less than $1 \cdot 8$.

Methods of determination of protein quality often accompany protein quality measures. Reference is usually made to specific methods in external publications such as specific editions of the Official Methods of Analysis of the Association of the Official Analytical Chemists ${ }^{(8)}$ or the 1991 Report of the joint FAO/WHO Expert Consultation on Protein Quality Evaluation $^{(12)}$. Alternatively, Canada developed its own official method for a protein rating ${ }^{(11)}$ that takes account of a food's protein content and quality.

\section{Protein quality in more detail}

Table 4 lists the regulatory provisions of the jurisdictions and Codex that prescribe protein quality criteria and methods of determination listing each measure of protein quality in order. The most common measure is protein efficiency ratio (PER) followed by an identified reference protein with no further details followed by amino acid profile then equal last, protein digestibility corrected amino acid score (PDCAAS) and protein rating.

The first-listed measure of protein quality is an amino acid profile of a reference protein or food. There are two possibilities for the profile: breast milk ( $\mathrm{mg}$ amino acid/g protein) applicable to infant and follow-on/up formulas, or casein for processed cereal-based foods for infants and young children containing 'added protein'. The use of an amino acid profile of breast milk accords with the recommendation in section $6 \cdot 3$ of the 1991 Report on Protein Quality Evaluation ${ }^{(12)}$ that:

The amino acid composition of human milk should be the basis of the scoring pattern to evaluate protein qual-

ity in foods for infants under one year of age.

In relation to infant formula and follow-on/up formula, the jurisdictions and Codex variously describe amino acids as dietary 'essential' and 'semi-essential' or 'indispensable' and 'conditionally indispensable'. Also, the amino acid cysteine is variously referred to as 'cysteine' (Codex); 'cystine' (Europe); or 'cysteine, cystine or combined cysteine and cystine' (Australia New Zealand). The European regulatory text derived the dietary indispensable and conditionally indispensable amino acid profile from the mean of six studies of the amino acid composition of breast milk adjusted to the given minimum crude protein content ${ }^{(13,14)}$. Codex lists the 
Table 4. Protein quality criteria and methods of determination according to measure of protein quality ${ }^{(4-7)}$

Food
Amino acid composition
Infant formula; Follow-on formula

Infant formula; Follow-on formula

(ANZ and EU only)

Processed cereal-based foods for infants and young children

Protein quality criteria

Minimum prescribed or reference amino acid profile of 11 essential and semi-essential amino acids as $\mathrm{mg} / 100 \mathrm{kcal}$ or $/ 100 \mathrm{~kJ}$ :

histidine; isoleucine; leucine; lysine; cysteine/cystine, methionine; phenylalanine, tyrosine; threonine; tryptophan; valine.

The chemical index of added protein at least $80 \%$ casein or PER of the food at least $70 \%$ casein.

\section{Protein digestibility-corrected amino acid score or chemical index}

Foods for energy-restricted diets for weight reduction

Formula foods for very low energy diets for weight reduction

Protein declaration in nutrition labelling (other than infant foods)

\section{Protein Efficiency Ratio}

Reference protein - Casein

Macaroni - enriched products with fortified protein

Peanut spreads ( $<90 \%$ peanuts)

Whole fish protein concentrate

Infant formula (new or major change in formulation related to protein quality)
Chemical index of protein equal to amino acid require$100 \%$, but not lower than $80 \%$, minimum protein levels to be correspondingly increased.

Minimum $50 \mathrm{~g}$ protein with protein digestibility-corrected amino acid score of 1 in recommended daily intake of energy.

\section{When PDCAAS is:}

$<20 \%$ for foods for adults and children aged 4 years or more, or $<40 \%$ for foods for children aged 1 to less than 4 years, then label declaration of protein to be modified by adding a statement "not a significant source of protein" or declaring a "corrected amount of protein' expressed as Percent Daily Value per serving.

Minimum protein quality $95 \%$ casein as determined on cooked food by specific method.

Minimum protein content $24 \%$ and biological quality of content $16.6 \%$ and biological quality of the protein

Protein quality not less than $100 \%$.

Minimum protein content $1.8 \mathrm{~g} / 100$ kilocalories when its protein quality equivalent to or better than casein. If protein quality less than casein, minimum amount of protein to be increased proportionately to compensate for its lower quality. Minimum protein quality $70 \%$ casein. ment pattern for adults. If chemical index lower than the protein at least $68 \%$ of casein; or Minimum protein

equal to or greater than casein.
Method of determination

Jurisdiction

Specified amino acid composition of breast milk adjusted to minimum regulatory protein content from:

- FAO, $1991^{(12)}$; or

Australia

New Zealand;

European Union;

Codex Alimentarius

- mean of six studies;

- seven studies and their mean.

Chemical index not further specified.

European Union

Amino acid composition of casein specified (includes arginine). PER method not specified.

Chemical index is the lowest of the ratios of each essential amino acid in test protein and amino acid requirement pattern. WHO Energy and Protein Requirements Report of a Joint FAO/WHO/UNU Meeting. Geneva WHO, 1985. (WHO Technical Report Series, 724) (26).

Report of the Joint FAO/WHO Expert Consultation on

Protein Quality Evaluation, Bethesda MD USA, 4-8

December 1989, FAO Food and Nutrition Paper No. 51, 1991, Rome p. $23^{(12)}$

'Corrected amount of protein' is actual amount of protein per serving multiplied by PDCAAS. If PDCAAS above $1 \cdot 00$, then set at $1 \cdot 00$. PCDAAS to be determined by methods given in sections 5.4.1, 7.2.1, and 8.00 in "Protein Quality Evaluation, Report of the Joint FAO/ WHO Expert Consultation on Protein Quality Evaluation," Rome, $1990^{(12)}$, except that food-specific $\mathrm{N}$

factors given in referenced AOAC methods to be used.

Biological Evaluation of Protein Quality (Protein Efficiency Ratio) Section 43.212- 43.216, AOAC, 13th edition, $1980^{(20)}$.

Biological Evaluation of Protein Quality (Protein Efficiency Ratio) Section 43.212- 43.216, AOAC, 13th edition, $1980^{(20)}$.

Biological Evaluation of Protein Quality (Protein Efficiency Ratio) Section 43.212- 43.216, AOAC, 13th edition, Ratio) Sectic
$1980^{(20)}$.

Biological quality of protein to be determined by appropriate modification of $A O A C$ rat bioassay method of analysis for vitamin D Section 43.195-43.208, AOAC, 13th edition, $1980^{(20)}$
European Union

Codex Alimentarius

United States

United States

United States

United States

United States 


\begin{tabular}{l} 
Food \\
\hline Follow-up formula \\
Processed cereal-based foods for \\
infants and young children \\
Formulated liquid diet (nutritionally \\
complete diet for oral or tube \\
feeding) \\
Protein declaration in nutrition
\end{tabular}

Pabelling (infant foods)
latein declaration in nutrition

Reference Protein - Egg or Milk Protein
Dried egg whites
Acidified milk, cultured milk,
eggnog, yoghurts
Protein rating
Simulated whole egg (with egg
albumin)
Meat or poultry product extender in
hydrated state; simulated meat or
poultry products
Protein content claim (source/excel-
lent source/more)

Protein quality criteria

Minimum $3 \mathrm{~g}$ protein $/ 100$ calories (or $0.7 \mathrm{~g} / 100$ kilojoules) of protein quality equivalent to casein or a greater quantity of other protein in inverse proportion to its protein quality. Minimum protein quality $85 \%$ casein.

Chemical index of added protein at least $80 \%$ casein or PER of the food at least $70 \%$ casein.

At least $20 \mathrm{~g}$ protein of protein quality equivalent to casein or proportionately higher amount of lower quality protein (not lower than $85 \%$ casein) in a reasonable daily intake.

When protein quality at least $40 \%$ PER of casein, a 'corrected amount of protein' expressed as Percent Daily Value per serving to be declared.

When protein quality less than $40 \%$ PER of casein, the label statement "not a significant source of protein" to be shown but not Percent Daily Value per serving.

Considered nutritionally equivalent to untreated egg whites if protein quality equal to or greater than untreated egg white from same batch of liquid egg white.

Addition of other [specified] optional ingredients to increase the nonfat solids of the food permitted providing the PER of all protein not decreased as a result.

Protein rating at least 40 .

Protein rating of $X$, [where $X$ is a particular rating of at least $20,23,28$ or 40 for a product].

Protein rating of at least 20/40/20 respectively (a) per reasonable daily intake; or (b) per $30 \mathrm{~g}$ combined with $125 \mathrm{~mL}$ of milk, if the food is a breakfast cereal.

Reference protein; no specified amino acid profile or method of determination

Human milk substitute

At least $1.8 \mathrm{~g}$ protein of protein quality equivalent to

casein or proportionately higher amount of lower quality protein (not lower than $85 \%$ casein) in 100 available kilocalories.

Meal replacement (for weight loss)

Protein content at least $20 \%$ energy. Protein quality equivalent to casein, or a quality and amount of at least $20 \%$ when protein quality is divided by casein quality and multiplied by percentage energy from protein content.

Formula foods for use in weight control diets

Protein quality equivalent to egg or milk protein, or if lower quality (not lower than $80 \%$ ), minimum conten increased to compensate.

Foods for very low energy diets At least $60 \mathrm{~g}$ protein of quality equivalent to casein or proportionately higher amount of lower quality protein (not lower than $85 \%$ casein) in daily allowance.
Method of determination

Jurisdiction

Protein quality to be determined provisionally using PER method in CODEX STAN 234-1999 ${ }^{(9)}$

Codex Alimentarius

No method of determination specified for chemical index PER: CODEX STAN 234-1999(9)

As determined by official method FO-1, Determination of Protein Rating, 15 October, $1981^{(11)}$.

'Corrected amount of protein' is actual amount of protein per serving multiplied by relative protein quality value determined by dividing subject food protein PER by PER for casein. If relative protein value above 1.00 ,

then set at 1.00 .

Protein Efficiency Ratio, Rat Bioassay Section 43.253-43.257, AOAC, 14th edition, $1984^{(21)}$

United States

No method of determination specified.

United States

As determined by official method FO-1, Determination of Protein Rating, 15 October, $1981^{(11)}$.

As determined by official method FO-1, Determination of Protein Rating, 15 October, $1981^{(11)}$.

As determined by official method FO-1, Determination of Protein Rating, 15 October, $1981^{(11)}$.

No amino acid profile or method of determination specified.

Codex Alimentarius

Canada

United States

Canada

Canada

Canada

Canada

No amino acid profile or method of determination specified.

No amino acid profile or method of determination specified.

No amino acid profile or method of determination specified.
Canada
Codex Alimentarius 
average amino acid profile reported by each of these six studies plus a seventh study from Japan as well as the mean of all seven studies adjusted to the given minimum crude protein content ${ }^{(15)}$. Alternatively, Australia New Zealand adjusted the amino acid profile of breast milk given in the 1991 Report on Protein Quality Evaluation ${ }^{(12)}$ to its minimum crude protein content ${ }^{(16,17)}$. Also, each of these three jurisdictions consistently permit the summation of cysteine/cystine and methionine; set a minimum proportion of cysteine/cystine; and permit the summation of tyrosine and phenylalanine, but only Australia New Zealand and Europe require a stated minimum proportion of phenylalanine.

The second-listed protein quality measure is the PDCAAS or 'chemical index'. The PDCAAS was recommended in the 1991 Report on Protein Quality Evaluation ${ }^{(12)}$ as "the most suitable approach for routine evaluation of protein quality", for both individual foods and diets. This measure was further recommended for official adoption at the international level. The PDCAAS is used for foods suitable for a low energy diet as well as for labelling of foods with poorer quality protein for consumers older than infants.

The minimum PDCAAS/"chemical index' is set at different levels according to regulatory purpose. At least $20 \%$ of the quality measure is prescribed for protein labelling but at least $80-100 \%$ of the measure is required for protein composition. The 1991 Report on Protein Quality Evaluation ${ }^{(12)}$ also made the interim recommendation that:

The amino acid scoring pattern proposed in 1985 by $\mathrm{FAO} / \mathrm{WHO} / \mathrm{UNU}$ for children of preschool age should be used to evaluate dietary protein quality for all age groups except infants.

The reference amino acid requirement pattern in support of this protein quality measure also differs among jurisdictions and Codex. In Europe, the adult amino acid requirement pattern is specified for foods for weight reduction ${ }^{(18)}$ whereas in the United States and Codex respectively, the pattern for preschool children given in the 1991 Report on Protein Quality Evaluation ${ }^{(12)}$ is used for protein labelling ${ }^{(7)}$ (21CFR101.9(c)(7)) and food for very low energy diets ${ }^{(19)}$.

The third-listed measure in Table 4 is the quality measure of PER as determined by rat bioassay method. This method is used predominantly in the United States and is referenced to the 13th or 14th editions of the official AOAC publication ${ }^{(20,21)}$. The method was subsequently numbered as AOAC $960 \cdot 48^{(8)}$. Regulations generally need to reference a particular edition of an external text and these editions would have been the most recently available at the time of gazettal. The PER method provides a biological assessment of protein quality of a food protein relative to reference casein by determining the weight gain (g) per protein intake (g) of young, weaned rats fed either the food protein or reference casein. Most protein quality criteria based on PER refer to a minimum proportion of casein of $40 \%$ for labelling and $68-100 \%$ casein for protein composition; however other criteria in the United States ${ }^{(7)}$ for egg- or milk-based foods refer respectively to egg white (21CFR160-145) or milk protein 
(1) At the end of 4 weeks calculate the protein efficiency ratio (PER) for each food and the reference standard protein, casein, using the following equation:

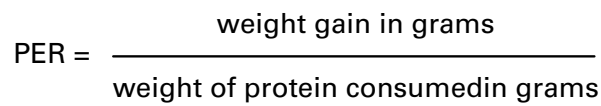

(2) Assuming that the case in has an average PER of 2.5 then determined under these conditions, adjust the PER of the test food as follows:

$$
\text { Adjusted PER }=\frac{\text { PER (test food) } \times 2.5}{\text { determined PER of standard reference casein }}
$$

(3) Calculate the protein rating (PR) of the test food as follows:

$\mathrm{PR}=$ Adjusted PER $\times$ grams protein in a reasonable daily intake of the food.

For example

If a food containing $10 \%$ protein $(n \times 6 \cdot 25)$ has an adjusted PER of 2.0 and if a reasonable daily intake of this food is 75 grams, the protein rating would be calculatedas follows:

Protein rating $=2.0 \times 0.1 \times 75$

$$
=15
$$

Fig. 1. Calculation steps from the Canadian Official Method for Determination of Protein Rating, $1981^{(11)}$.

(21CFR131·111; 21CFR131·112; 21CFR131·170; 21CFR131·200; 21CFR131-203; 21CFR131-206).

The regulation of protein quality of infant formula in the United States $^{(7)}$ (21CFR107-100) refers to appropriate modification of another rat bioassay method subsequently numbered as AOAC $936 \cdot 14^{(8)}$ for determination of vitamin D in milk. In 1996, the US Food and Drug Administration issued a proposed rule to revise the infant formula regulations inter alia to update the method of determination to AOAC $960 \cdot 48^{(8)}$. At that time, the United States tentatively concluded that ${ }^{(22)}$ :

...the rat bioassay is necessary to establish that the amino acids in a protein source are present, and that adequate amounts and proportions of all essential amino acids are capable of being digested by an infant.

Canada's regulation of protein quality, the fourth-listed measure of protein quality in Table 4 , is based on its official method for Protein Rating ${ }^{(11)}$ which takes account of both protein quality and protein content by adjusting the protein content in a reasonable daily intake of a food by the ratio of that food's PER to the standard reference casein PER set to a value of 2.5. The calculation steps are shown in Fig. 1. The 'reasonable daily intake' in the method is prescribed for foods listed in Schedule $\mathrm{K}$ of the Canadian Food and Drug Regulations ${ }^{(23)}$ and the details relating to the PER component are similar to AOAC method $960 \cdot 48^{(8)}$. Protein rating applies to more than half the Canadian regulations ${ }^{(5)}$ that address protein quality.

The last measure listed in Table 4 relates to the foods for which minimum protein quality criteria are established relative to casein quality but no further details are given. All of the listed foods fall into the special purpose food category. In each case, the protein quality and content are inter-related as previously discussed. The Codex guideline for formulated supplementary foods for older infants and young children ${ }^{(24)}$, refers to PDCAAS as the quality measure although it relates the amino acid profile of the supplementary food to casein rather than to an amino acid requirement.

\section{Conclusion}

Food regulation aims to control and guide the food industry in producing and marketing safe food. Protein content and protein quality are variously regulated by the surveyed jurisdictions and Codex but only for certain commodity and analogue foods, special purpose foods and for protein labelling. Regulation is prescribed to provide for a minimum product quality or nutritional quality to protect consumer health as well as to provide methods for the purpose of consistency and certainty in enforcement and compliance. Five measures of protein quality are used by the jurisdictions and Codex to regulate protein quality, mostly for special purpose foods. However, there is very little consistency within and between jurisdictions and Codex in relation to the type or extent of regulation of protein in foods.

International harmonisation of protein regulation for individual foods is likely to be a challenge but it could be facilitated through revision of the provisions regulating protein in the Codex Alimentarius ${ }^{(3)}$. However, since Codex texts are non-binding, achievement of more detailed harmonisation would depend on broad agreement on the application to, and specific details for, protein regulation of individual foods. Should PDCAAS be adopted, as endorsed in the 2007 WHO/FAO/UNU Report ${ }^{(27)}$, broad agreement would be needed on specific details such as the method of analysis of 
amino acids, the reference amino acid profile - food protein or human requirement, and the minimum proportion of the PDCAAS that should be met. In addition, unresolved issues identified in the $\mathrm{WHO} / \mathrm{FAO} / \mathrm{UNU}$ Report ${ }^{(27)}$ including the digestibility of protein and the concept of protein quality values that exceed 100 would need agreement.

\section{Acknowledgements}

The author thanks colleagues in the European Commission, Health Canada and US Food and Drug Administration for their professional advice and kind assistance. There are no financial or other conflicts of interest.

\section{References}

1. Commonwealth of Australia (2011) Food Standards Australia New Zealand Act 1991; available at http://www.comlaw.gov. au/Details/C2011C00117 (accessed March 2011).

2. Codex Alimentarius Commission (2010) Procedural Manual 19th ed.; available at ftp://ftp.fao.org/codex/Publications/ ProcManuals/Manual_19e.pdf (accessed March 2011).

3. Codex Alimentarius Commission (2010) Codex Alimentarius; available at http://www.codexalimentarius.net/web/standard list.do?lang=en (accessed March 2011).

4. Food Standards Australia New Zealand (2011) Australia New Zealand Food Standards Code; available at http://www. foodstandards.gov.au/foodstandards/foodstandardscode. cfm (accessed March 2011).

5. Health Canada (2011) Food and Drug Regulations; available at http://laws.justice.gc.ca/eng/c.r.c.-c.870/index. html (accessed March 2011).

6. European Commission (2011) Directorate General for Health and Consumers, Food and Feed Safety home page; available at http://ec.europa.eu/food/food/index_en.htm (accessed March 2011).

7. Food and Drug Administration (2010) The Code of Federal Regulations Title 21; available at http://www.accessdata. fda.gov/scripts/cdrh/cfdocs/cfcfr/cfrsearch.cfm (accessed March 2011).

8. Association of Official Analytical Chemists (1920) Official Methods of Analysis of the Association of Official Analytical Chemists. Arlington: AOAC.

9. Codex Alimentarius Commission (2007) Recommended Methods of Analysis and Sampling CODEX STAN 234 - 1991; available at http://www.codexalimentarius.net/download/ standards/388/CXS_234e.pdf (accessed March 2011).

10. Codex Committee on Methods of Analysis and Sampling (2008) Report of the 29th Session. ALINORM 08/31/23; available at http://www.codexalimentarius.net/download/ report/699/al31_23e.pdf (accessed March 2011).

11. Health Canada (1981) Official Method for Determination of Protein Rating, FO-1, October 15, 1981; available at http:// www.hc-sc.gc.ca/fn-an/alt_formats/hpfb-dgpsa/pdf/res-rech/ fo-1-eng.pdf (accessed March 2011).

12. Food and Agriculture Organization of the United Nations (1991) Protein Quality Evaluation. Report of a Joint FAO/ WHO Expert Consultation. FAO Food and Nutrition Paper no. 51. Rome: FAO.

13. Scientific Committee on Food (2003) Report of the Scientific Committee on Food on the Revision of Essential Requirements of Infant Formulae and Follow-on Formulae; available at http://ec.europa.eu/food/fs/sc/scf/out199_en.pdf (accessed March 2011)
14. European Commission (2006) Commission Directive 2006/ 141/EC of 22 December 2006 on infant formulae and follow-on formulae and amending Directive 1999/21/EC; available at http://eur-lex.europa.eu/LexUriServ/LexUriServ. do?uri=OJ:L:2006:401:0001:0033:EN:PDF (accessed March 2011).

15. Codex Alimentarius Commission (2007) Standard for infant formulas and formulas for special medical purposes intended for infants CODEX STAN 72 - 1981; available at http://www.codexalimentarius.net/download/standards/ 288/CXS_072e.pdf (accessed March 2011).

16. Food Standards Australia New Zealand (2009) Australia New Zealand Food Standards Code. Standard 2.9.1 - Infant Formula Products; available at http://www.foodstandards.gov. au/_srcfiles/Standard_2_9_1_Infant_Formula_Products_ v109.pdf (accessed March 2011).

17. Australia New Zealand Food Authority (2002) Proposal P93 - Review of Infant Formula. Supplementary Final Assessment Report; available at http://www.foodstandards.gov. au/_srcfiles/P93_completeFinalAssRep(supplement).pdf (accessed March 2011).

18. European Commission (2006) Commission Directive 96/8/EC of 26 February 1996 on foods intended for use in energyrestricted diets for weight reduction; available at http://eurlex.europa.eu/LexUriServ/LexUriServ.do?uri=CONSLEG:1996 L0008:20070620:EN:PDF (accessed March 2011)

19. Codex Alimentarius Commission (2007) Standard for formula foods for use in very low energy diets for weight reduction CODEX STAN 203 - 1995; available at http:// www.codexalimentarius.net/download/standards/296/CXS 203e.pdf (accessed March 2011).

20. Association of Official Analytical Chemists [W Horwitz, editor]. Official Methods of Analysis of the Association of Official Analytical Chemists, 13th ed. Arlington: AOAC.

21. Association of Official Analytical Chemists [S Williams, editor]. Official Methods of Analysis of the Association of Official Analytical Chemist, 14th ed. Arlington: AOAC.

22. US Food and Drug Administration (1996) Current Good Manufacturing Practice, Quality Control Procedures, Quality Factors, Notification Requirements, and Records and Reports, for the Production of Infant Formula Proposed rule. Federal Register 61FR36153 July 9, 1996; available at http://frwebgate.access.gpo.gov/cgi-bin/getpage.cgi?position =all\&page=36154\&dbname=1996_register (accessed March 2011).

23. Health Canada (2011) Food and Drug Regulations. Schedule $K$; available at http://laws.justice.gc.ca/eng/c.r.c.-c.870/page5.html (accessed March 2011).

24. Codex Alimentarius Commission (1991) Guidelines on formulated supplementary foods for older infants and young children CAC/GL 08 - 1991; available at http://www. codexalimentarius.net/download/standards/298/CXG_008e. pdf (accessed March 2011).

25. Food Standards Australia New Zealand (2009) Proposal P293 Nutrition, health \& related claims. Consultation paper for first review; available at http://www.foodstandards.gov. au/_srcfiles/P293\%20Health\%20Claims\%20Cons\%20Paper\% 20FINAL.pdf (accessed March 2011).

26. World Health Organization (1985) Energy and Protein Requirements. Report of a Joint FAO/WHO/UNU Meeting. Technical Report Series no. 724. Geneva: WHO.

27. World Health Organization (2007) Protein and Amino Acid Requirements in Human Nutrition. Report of a Joint WHO/ FAO/UNU Expert Consultation. Technical Report Series no. 935. Geneva: WHO. 